http://dx.doi.org/10.1590/0370-44672019730115

Matheus Miranda de Oliveira ${ }^{1,3}$

https://orcid.org/0000-0002-4098-6383

Lucas Roquete ${ }^{2,4}$

https://orcid.org/0000-0002-7937-822X

Arlene Maria Cunha Sarmanho ${ }^{1,5}$

https://orcid.org/0000-0001-6900-8551

Daniel Jose Rocha Pereira ${ }^{1,6}$

https://orcid.org/0000-0002-7291-5598

Vinicius Alves ${ }^{1,7}$

https://orcid.org/0000-0002-8572-0722

1 Universidade Federal de Ouro Preto - UFOP, Escola de Minas, Departamento de Engenharia Civil, Ouro Preto - Minas Gerais - Brasil.

${ }^{2}$ Universidade Federal de São João del-Rei - UFSJ, Departamento de Tecnologia em Engenharia Civil DTECH, Ouro Branco - Minas Gerais - Brasil.

E-mails: ${ }^{3}$ matheusmoliveira4@gmail.com, 4lucasroquete@gmail.com,

5arlene.sarmanho@gmail.com,

ㅎrocha044@gmail.com, vnichio@hotmail.com

\section{Bearing failure in bolted sleeve connections with circular hollow sections under compression}

\begin{abstract}
This article analyzes sleeve connections between circular hollow sections. This type of connection is composed of two tubes connected by bolts to an inner tube with a smaller diameter, and explores the efficiency, aesthetics and resistance of hollow sections subjected to tension and compression. In previous researches, sleeve connections with aligned and crossed bolt dispositions and under axial tension were studied. Herein, the behavior of sleeve connections with aligned bolts and under compression was analyzed. A model to represent the connection using the finite element method was developed, which allowed a numerical analysis with geometric property variations. In the numerical/parametric results, bearing failure was observed in all cases, either in the outer or inner tube. Limiting the number of bolts to 6 and considering that connections have a lower outer thickness than the inner tube, a formulation was proposed to determine the ultimate bearing capacity of sleeve connections under compression and with bearing failure.
\end{abstract}

Keywords: sleeve connections, circular hollow sections, numerical analysis. 


\section{Introduction}

Steel hollow sections have excellent mechanical and geometrical characteristics that provide good structural behavior under axial forces, torsion and combined effects (Wardenier et al., 2010). Tubular sections are found in square (SHS), circular (CHS) or rectangular (RHS) geometric shapes, and their use enables the creation of lightweight structures with possibly wide spans (Araújo et al., 2016).

The design of connections between tubular sections requires attention, since joints can be regions with high stress concentrations - besides the geometric properties that challenge the execution of a connection between these sections. The sleeve connection is a solution that offers a good visual aspect and allows the use of standardized elements (Amparo, 2014).

The sleeve connection is composed of two tubes with circular sections connected by bolts to an inner tube with a smaller diameter - Figure 1. The connection allows harmony in the continuity of the profile, aesthetically inducing a continuity of elements connected to the real structure.

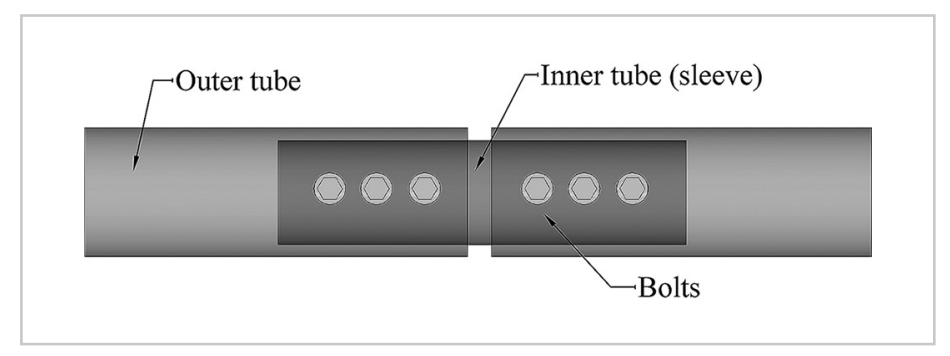

Figure 1 - Sleeve connection with six aligned bolts.

Sleeve connections can also be made of different types of sections and materials, as shown in recent studies (Liu et al., 2015; Luo et al., 2016; Natesan and Madhavan, 2019; Zhang et al., 2016). Researches on sleeve connections between steel circular hollow sections began in 2011, with the study of Vieira et al. (2011), that identified the shear lag coefficient values on two numerical models with three and four aligned bolts and under axial tension.

The shear lag coefficient was also approached by Roquete et al. (2017b), who analyzed two bolt configurations: aligned and crossed bolts. Experimental results of 12 prototypes with a variable number of bolts $-3,4$ and 5 bolts -, bolt configurations, diameters and thicknesses of the tubes were undertaken, and its shear lag coefficients obtained.

Also analyzing sleeve connections under tension, Silva (2012) observed a predominant failure mode occurring on the bolts. The author, through 28 experimental prototypes - that varied the number of bolts, thickness and diameter of the outer and inner tubes - proposed an expression to calculate the joint resistance of sleeve connections that fail under the bending of bolts.

Several other studies (Amparo, 2014; Amparo et al., 2015a, 2015b, 2016; Roquete, 2018; Roquete et al., 2017a; Vieira, 2014) evaluated sleeve connections with different geometric and material properties, number of bolts, bolt configurations and failure modes, all under axial tension.

Therefore, the study of sleeve connections under axial compression has not yet been approached and is the subject of this research. This article aims to evaluate - through numerical analysis - the behavior of 29 sleeve connections with aligned bolts and with bearing failure as the dominant case, varying the number of bolts, the diameter and thickness of the outer and inner tubes, and to propose an equation that determines the resistance of a sleeve connection under bearing failure.

\section{Materials and methods}

\subsection{Geometric and material properties}

Finite element modeling of sleeve connections was performed using the commercial software ANSYS (ANSYS Inc., 2012). The finite element type and mesh size were varied using the properties of the model described in Table 1. After the study of these parameters, a

parametric study with variations in the number of bolts and geometric properties of the connection components was performed - Table 4.

The model used for these numerical variations had aligned bolts, two outer tubes, one inner tube and
8 bolts. Two types of steel were considered, one for the tubes and another for the bolts - Table 1. Multilinear stress-strain curves were used, as presented by Salmon and Johnson (1990), with a nominal Young's modulus of $200000 \mathrm{MPa}$.

Table 1 - Geometry and materials.

\begin{tabular}{|c|c|c|c|c|c|c|c|c|c|c|c|}
\hline \multirow{4}{*}{ 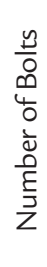 } & \multicolumn{4}{|c|}{ Outer tube } & \multicolumn{4}{|c|}{ Inner tube } & \multicolumn{3}{|c|}{ Bolts } \\
\hline & \multirow{3}{*}{ 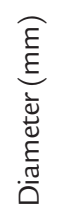 } & \multirow{3}{*}{ 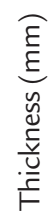 } & \multicolumn{2}{|c|}{ Steel Resistance } & \multirow{3}{*}{ 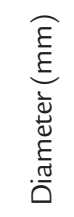 } & \multirow{3}{*}{ 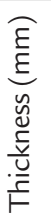 } & \multicolumn{2}{|c|}{ Steel Resistance } & \multirow{3}{*}{ 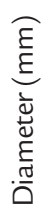 } & \multicolumn{2}{|c|}{ Steel Resistance } \\
\hline & & & yielding & ultimate & & & yielding & ultimate & & yielding & ultimate \\
\hline & & & $\mathrm{f}_{y}(\mathrm{MPa})$ & $\mathrm{f}_{\mathrm{u}}(\mathrm{MPa})$ & & & $\mathrm{f}_{y}(\mathrm{MPa})$ & $\mathrm{f}_{\mathrm{u}}(\mathrm{MPa})$ & & $\mathrm{f}_{\mathrm{y}}(\mathrm{MPa})$ & $\mathrm{f}_{\mathrm{u}}(\mathrm{MPa})$ \\
\hline 8 & 73 & 5.6 & 350 & 485 & 60.3 & 8.0 & 350 & 485 & 16 & 635 & 825 \\
\hline
\end{tabular}


The distance between bolts was adopted according to ABNT NBR 8800 (2008) recommendations, with a hole-to-hole distance value of 3 times

\subsection{Boundary conditions}

The simulation of axial compression in the outer tube was performed by applying increments of displacements, with the solution of NewtonRaphson iterative method.

At one end, the outer tube was

\subsection{Finite element}

The shell element SHELL181 was attributed to the tubes, and different solid finite elements - SOLID 185 and SOLID 186 - were tested for the bolts.

SHELL181 is suitable for analyzing thin to moderately thick shell structures. It is a 4-node element with six degrees of freedom at each node: translations and rotations about the $\mathrm{x}, \mathrm{y}$, and $\mathrm{z}$ axes. It is well-suited for linear, large rotation, and/ or large strain nonlinear applications. It has been previously used to simulate sleeve connections, in the articles of Vieira (2014) and Roquete (2018).

SOLID185 is used for 3-D modeling of solid structures and is defined by eight the bolt diameter $\left(3 \mathrm{~d}_{\mathrm{b}}\right)$ and the holeto-edge distance of 2.7 times the bolt diameter $\left(2.7 d_{b}\right)$. Standard hole diameters were considered, defined by add-

considered as a fixed support, with displacements and rotations prevented in all directions. At the other end, nodes were free to move in the axial direction of the displacement application, to enable the simulation

nodes having three degrees of freedom each: translations in the nodal $\mathrm{x}, \mathrm{y}$, and $\mathrm{z}$ directions. It simulates the behavior of plasticity, hyperelasticity, stress stiffening, creep, large deflection, and large strain capabilities. SOLID186 is a higher order 3-D 20-node solid element that exhibits quadratic displacement behavior and is defined by 20 nodes having the same three degrees of freedom per node as SOLID 185. A higher-order version of the SOLID185 element is SOLID186.

To simulate the contact of the bolts with the transverse section of the tube, the contact pair CONTA175 and TARGE170 were used. TARGE170 is used to represent various 3-D "target" surfaces for the asso- ing a $1.5 \mathrm{~mm}$ gap to the bolt diameter $\left(d_{b}\right)$. To prevent the outer tubes from touching, $30 \mathrm{~mm}$ distances were used between them.

of compression.

To avoid rigid body displacements, the ends of the bolts were coupled, and its displacements restricted in the direction perpendicular to the displacements applied in the tubes.

ciated contact elements. CONTA175 may be used to represent contact and sliding between two surfaces and it is applicable to 2-D or 3-D structural and coupled field contact analyses. Contact occurs when the element surface penetrates one of the target segment elements (TARGE170) on a specified target surface. The coefficient of friction was taken as 0.35 , as recommended by ANBT NBTR 8800 (2008) and used by Vieira (2014) and Roquete (2018).

A comparison between the quantity of nodes and elements, maximum load, processing time when using the two different solid elements are shown in Table 2, and the connection behavior in Figure 2 .

Table 2 - Results of the study of elements.

\begin{tabular}{c|c|c|c|c}
\hline Models & No. of elements & No. of nodes & Maximum load $(\mathrm{kN})$ & Processing time $(\mathrm{min})$ \\
\hline SHELL181+SOLID186 & 21022 & 24684 & 428.95 & 31.45 \\
\hline SHELL181+SOLID185 & 20407 & 11350 & 429.57 & 36.97 \\
\hline
\end{tabular}

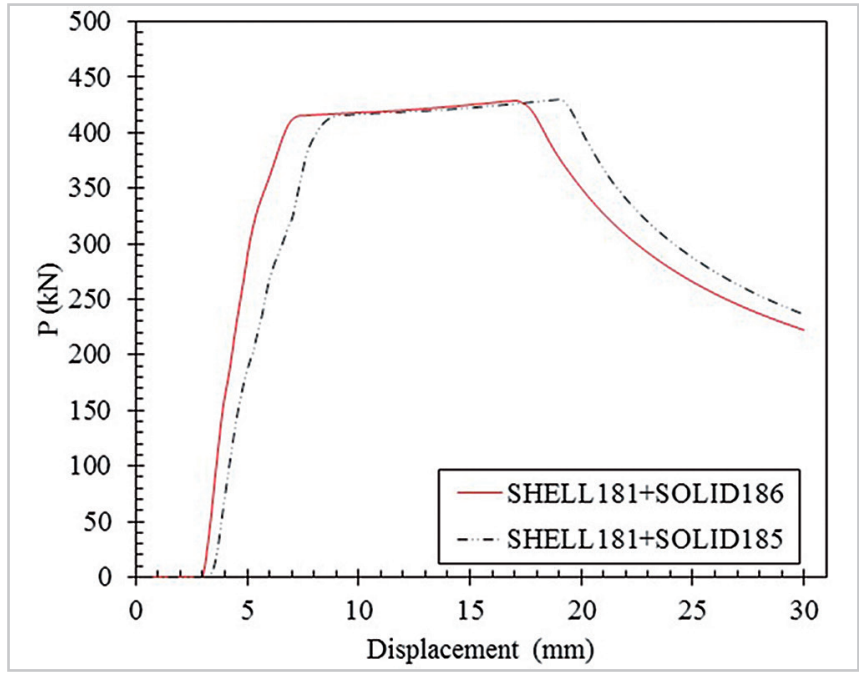

Figure 2 - Elements comparison.

Analyzing the load versus displacement graph - Figure 2, the model with SOLID185 began to interact after a $3 \mathrm{~mm}$ displacement, which exceeds the maximum gap that separates bolts from getting into contact with the holes. Since the values obtained for maximum load and processing time when using the combination of SHELL181 with either one of the solid elements were similar, with a $0.14 \%$ load difference, the elements SHELL181 for the tubes and SOLID186 for the bolts were chosen for the parametric analysis. 


\subsection{Mesh study}

Free mesh was chosen for the analysis. Three different mesh size configurations were tested: fine, medium and coarse. The number of elements and nodes, maximum load encountered, and processing time of each configuration is shown in Table 3.

Table 3 - Results of the study of mesh.

\begin{tabular}{|c|c|c|c|c|c|c|}
\hline \multirow{2}{*}{ Mesh } & \multicolumn{2}{|c|}{ Mesh size } & \multirow{2}{*}{ No. of elements } & \multirow{2}{*}{ No. of nodes } & \multirow{2}{*}{$\begin{array}{c}\text { Maximum load } \\
(\mathrm{kN})\end{array}$} & \multirow{2}{*}{$\begin{array}{l}\text { Processing time } \\
\qquad(\min )\end{array}$} \\
\hline & Bolts $(\mathrm{mm})$ & Tubes $(\mathrm{mm})$ & & & & \\
\hline Fine & 4 & 4 & 38276 & 43864 & 428.12 & 206.85 \\
\hline Medium & 5 & 6 & 21022 & 24684 & 428.95 & 31.45 \\
\hline Coarse & 6 & 9 & 13452 & 16138 & 432.49 & 38.75 \\
\hline
\end{tabular}

The medium mesh model presented shorter processing time and better efficiency to represent the bolted sleeve connection - Figure 3. The maximum load difference between the models was not considered relevant, with a difference of $0.19 \%$. Therefore, the medium mesh Figure 4 - was adopted for the models in the parametric analysis.

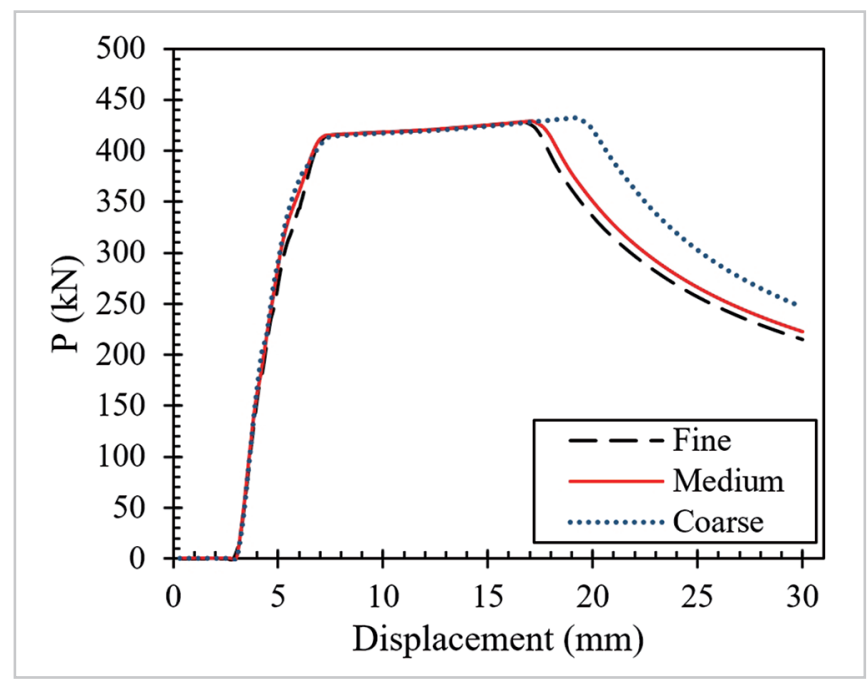

Figure 3 - Mesh sizes comparison.

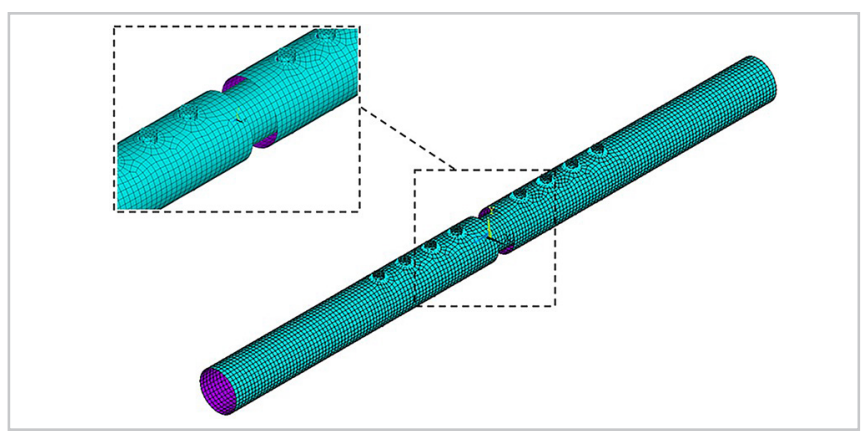

Figure 4 - Model with mesh.

\subsection{Failure criterion}

It was assumed that excessive material deformation characterized bearing failure and shear failure of bolts, a

\subsection{Parametric study}

Even though experimental results to validate a numerical model of sleeve connections under compression are not available, a similar finite elements model of this connection has been validated under tension by Roquete (2018). Thus, the development of a parametric study is important to the criterion also used by Vieira (2014) and Roquete (2018). When the deformation of von Mises exceeds the ultimate

progress of researches about these joints under compression, with the contribution of the possible failure modes and deformation behavior under the specific geometric properties assessed in this study.

Using the described numerical model, a parametric analysis of the rupture deformation of the material, failure occurs.

bolted sleeve connection under compression was performed, maintaining the same mechanical characteristics presented in Table 1. The geometric parameters of the connection were varied: inner and outer tube diameters and thicknesses, bolt diameter and number of bolts - Table 4 . 
Table 4 - Geometric data of the parametric study.

\begin{tabular}{|c|c|c|c|c|c|c|}
\hline \multirow{2}{*}{$\begin{array}{l}\text { Model } \\
\text { Number }\end{array}$} & \multirow{2}{*}{$\begin{array}{c}\text { Number of } \\
\text { bolts }\end{array}$} & \multicolumn{2}{|c|}{ Outer tube } & \multicolumn{2}{|c|}{ Inner tube } & \multirow{2}{*}{$\begin{array}{c}\text { Bolts } \\
\text { Diameter } \\
(\mathrm{mm})\end{array}$} \\
\hline & & $\begin{array}{c}\text { Diameter } \\
(\mathrm{mm})\end{array}$ & $\begin{array}{c}\text { Thickness } \\
(\mathrm{mm})\end{array}$ & $\begin{array}{l}\text { Diameter } \\
(\mathrm{mm})\end{array}$ & $\begin{array}{c}\text { Thickness } \\
(\mathrm{mm})\end{array}$ & \\
\hline 1 & 4 & 73.0 & 5.6 & 60.3 & 5.6 & 16.0 \\
\hline 2 & 4 & 73.0 & 5.6 & 60.3 & 6.4 & 16.0 \\
\hline 3 & 4 & 73.0 & 5.6 & 60.3 & 7.1 & 16.0 \\
\hline 4 & 4 & 73.0 & 5.6 & 60.3 & 8.0 & 16.0 \\
\hline 5 & 4 & 73.0 & 5.6 & 60.3 & 8.8 & 16.0 \\
\hline 6 & 6 & 73.0 & 5.6 & 60.3 & 5.6 & 16.0 \\
\hline 7 & 6 & 73.0 & 5.6 & 60.3 & 6.4 & 16.0 \\
\hline 8 & 6 & 73.0 & 5.6 & 60.3 & 7.1 & 16.0 \\
\hline 9 & 6 & 73.0 & 5.6 & 60.3 & 8.0 & 16.0 \\
\hline 10 & 6 & 73.0 & 5.6 & 60.3 & 8.8 & 16.0 \\
\hline 11 & 8 & 73.0 & 5.6 & 60.3 & 5.6 & 16.0 \\
\hline 12 & 10 & 73.0 & 5.6 & 60.3 & 5.6 & 16.0 \\
\hline 13 & 12 & 73.0 & 5.6 & 60.3 & 5.6 & 16.0 \\
\hline 14 & 6 & 88.9 & 5.6 & 73.0 & 8.0 & 17.5 \\
\hline 15 & 6 & 88.9 & 5.6 & 73.0 & 8.0 & 19.0 \\
\hline 16 & 4 & 88.9 & 5.6 & 73.0 & 8.8 & 17.5 \\
\hline 17 & 4 & 88.9 & 5.6 & 73.0 & 8.8 & 19.0 \\
\hline 18 & 4 & 88.9 & 5.6 & 73.0 & 8.8 & 22.0 \\
\hline 19 & 6 & 73.0 & 4.0 & 60.3 & 7.1 & 16.0 \\
\hline 20 & 6 & 73.0 & 4.5 & 60.3 & 7.1 & 16.0 \\
\hline 21 & 6 & 73.0 & 5.0 & 60.3 & 7.1 & 16.0 \\
\hline 22 & 6 & 73.0 & 5.6 & 60.3 & 7.1 & 16.0 \\
\hline 23 & 6 & 88.9 & 4.5 & 73.0 & 8.0 & 19.0 \\
\hline 24 & 6 & 88.9 & 5.0 & 73.0 & 8.0 & 19.0 \\
\hline 25 & 6 & 88.9 & 5.6 & 73.0 & 8.0 & 19.0 \\
\hline 26 & 6 & 88.9 & 6.4 & 73.0 & 8.0 & 19.0 \\
\hline 27 & 6 & 88.9 & 7.1 & 73.0 & 8.0 & 19.0 \\
\hline 28 & 6 & 101.6 & 5.0 & 88.9 & 8.8 & 22.0 \\
\hline 29 & 6 & 101.6 & 5.6 & 88.9 & 8.8 & 22.0 \\
\hline
\end{tabular}

\section{Results}

In all models analyzed, bearing failure was the dominant failure mode observed. In models with 4 bolts, bolt shear failure was observed right after the occurrence of bearing failure.
Figure 5 shows the von Mises stress distribution on the region of holes in Model 15, where this failure can be observed.

The numerical load results that deter- mine the joint resistance through the failure criterion of excessive material deformation are shown in Table 5, for each model. Failures in the outer (OUT) or inner (IN) tubes were detected.

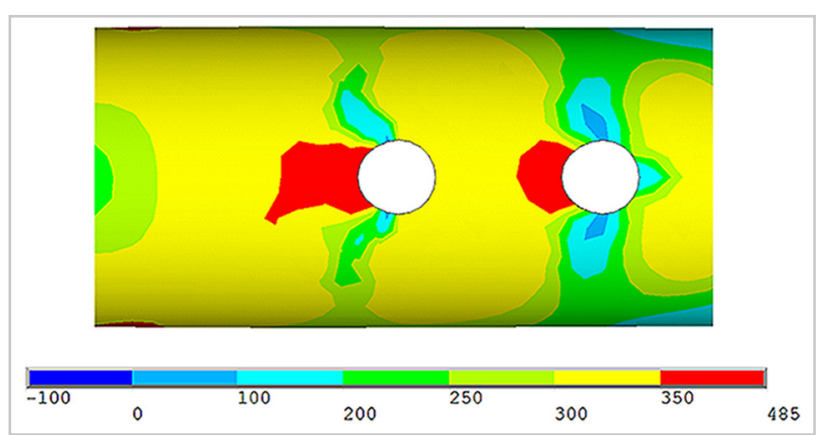

Figure 5 - Stress distribution [MPa] of Model 15. 
Table 5 - Numerical, theoretical and proposed results for bearing failure.

\begin{tabular}{|c|c|c|c|c|c|c|c|}
\hline \multirow[b]{2}{*}{$\begin{array}{l}\text { Model } \\
\text { Number }\end{array}$} & \multirow[b]{2}{*}{$\begin{array}{l}\text { Number of } \\
\text { bolts }\end{array}$} & \multirow[b]{2}{*}{ Tube Failure } & \multirow[b]{2}{*}{$\begin{array}{l}\text { Numerical } \\
\text { Load }(k N)\end{array}$} & \multicolumn{2}{|c|}{ NBR Comparison } & \multicolumn{2}{|c|}{ Proposed formulation comparison } \\
\hline & & & & $\begin{array}{l}\text { NBR8800 } \\
\text { Load }(k N)\end{array}$ & $\begin{array}{l}\text { Num. Load/ } \\
\text { NBR8800 Load }\end{array}$ & $\begin{array}{l}\text { Proposed } \\
\text { Load }(k N)\end{array}$ & $\begin{array}{c}\text { Num. Load/ } \\
\text { Proposed Load (kN) }\end{array}$ \\
\hline 1 & 4 & OUT & 277.70 & 417.18 & 0.666 & - & - \\
\hline 2 & 4 & OUT & 279.22 & 417.18 & 0.669 & - & - \\
\hline 3 & 4 & OUT & 278.96 & 417.18 & 0.669 & - & - \\
\hline 4 & 4 & OUT & 276.83 & 417.18 & 0.664 & - & - \\
\hline 5 & 4 & OUT & 276.23 & 417.18 & 0.662 & - & - \\
\hline 6 & 6 & IN & 376.57 & 625.77 & 0.602 & - & - \\
\hline 7 & 6 & OUT & 401.27 & 625.77 & 0.641 & 409.56 & 0.980 \\
\hline 8 & 6 & OUT & 404.07 & 625.77 & 0.646 & 409.56 & 0.987 \\
\hline 9 & 6 & OUT & 403.63 & 625.77 & 0.645 & 409.56 & 0.986 \\
\hline 10 & 6 & OUT & 402.73 & 625.77 & 0.644 & 409.56 & 0.983 \\
\hline 11 & 8 & IN & 346.00 & 834.36 & 0.415 & - & - \\
\hline 12 & 10 & IN & 412.00 & 1042.94 & 0.395 & - & - \\
\hline 13 & 12 & IN & 414.27 & 1251.53 & 0.331 & - & - \\
\hline 14 & 6 & OUT & 431.36 & 684.43 & 0.630 & 447.96 & 0.963 \\
\hline 15 & 6 & OUT & 473.24 & 743.10 & 0.637 & 486.36 & 0.973 \\
\hline 16 & 4 & OUT & 294.80 & 456.29 & 0.646 & - & - \\
\hline 17 & 4 & OUT & 318.41 & 495.40 & 0.643 & - & - \\
\hline 18 & 4 & OUT & 360.03 & 573.62 & 0.628 & - & - \\
\hline 19 & 6 & OUT & 291.50 & 446.98 & 0.652 & 292.55 & 0.996 \\
\hline 20 & 6 & OUT & 330.15 & 502.85 & 0.657 & 329.11 & 1.003 \\
\hline 21 & 6 & OUT & 362.23 & 558.72 & 0.648 & 365.68 & 0.991 \\
\hline 22 & 6 & OUT & 404.55 & 625.77 & 0.646 & 409.56 & 0.988 \\
\hline 23 & 6 & OUT & 370.72 & 597.13 & 0.621 & 390.82 & 0.949 \\
\hline 24 & 6 & OUT & 412.71 & 663.48 & 0.622 & 434.25 & 0.950 \\
\hline 25 & 6 & OUT & 472.65 & 743.10 & 0.636 & 486.36 & 0.972 \\
\hline 26 & 6 & OUT & 534.94 & 849.25 & 0.630 & 555.84 & 0.962 \\
\hline 27 & 6 & OUT & 576.81 & 942.14 & 0.612 & 616.63 & 0.935 \\
\hline 28 & 6 & OUT & 477.98 & 768.24 & 0.622 & 502.81 & 0.951 \\
\hline 29 & 6 & OUT & 529.15 & 860.43 & 0.615 & 563.15 & 0.940 \\
\hline Mean & & & & & 0.614 & & 0.971 \\
\hline $\mathrm{CoV}$ & & & & & 0.670 & & 0.040 \\
\hline
\end{tabular}

As a comparison, theoretical values were obtained using Equation 1, recom- mended by ABNT NBR 8800 (2008) to determine the ultimate load resistance

$$
\mathrm{F}_{\mathrm{c}, \mathrm{Rk}}=2.4 \mathrm{~d}_{\mathrm{b}} \mathrm{t}_{\text {out }} \mathrm{f}_{\mathrm{u}}
$$

where:

$\mathrm{d}_{\mathrm{b}}$ - bolt diameter;

$\mathrm{t}_{\text {out }}$ - thickness of outer tube;

$f_{u}$ - ultimate steel resistance of tube.

The results of Equation 1 for each model are in Table 5. In Figure 6, the ratio between the numerical and theoretical values using Equation 1 for each model is also presented, where it is possible to notice that all models presented numeri- of bearing failure for a section subjected to compression.

cal loads lower than the theoretical ones. Three models showed higher discrepancy - Models 11, 12 and 13 -, all characterized by more than 6 bolts in their configurations and failure in the inner tube. 


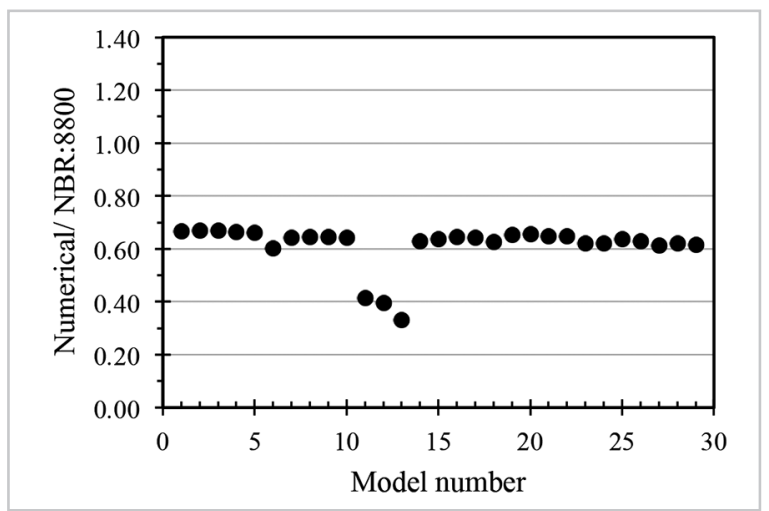

Figure 6 - Comparison between numerical and NBR 8800 loads.

The necessity of a more precise formulation to calculate the resistance to bearing failure in sleeve connections under compression was assessed.

\subsection{Proposed formulation}

Bearing failure can be characterized by excessive deformation of a tube
Since models with 4 bolts have a possibility of bolt shear failure and with more than 6 bolts presented failure in the inner tube, the models with these configurations were not considered in the analysis of a new formulation.

wall in contact with a bolt. The product of the area of contact - Figure 7 - by

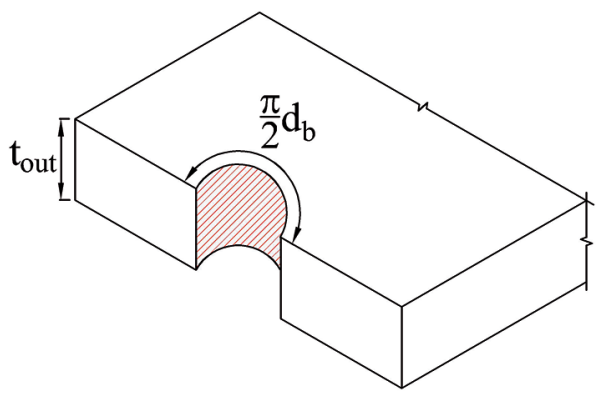

Figure 7 - Geometric details.

Thus, the product of half of the bolt circumference $\left(\pi \mathrm{d}_{b} / 2\right)$ by the thickness of the outer tube and the

steel ultimate strength can give the resistance force for bearing failure. Equation 2, then, is proposed to cal-

$$
F_{c, R k}=\frac{\pi}{2} d_{b} t_{\text {out }} f_{u}
$$

where:

$\mathrm{d}_{\mathrm{b}}$ - bolt diameter;

$\mathrm{t}_{\text {out }}-$ thickness of the outer tube; $\mathrm{f}_{\mathrm{u}}$ - steel ultimate strength.

The results of Equation 2 for each model of the parametric analysis are shown the steel strength is equal to the force acting in the region.

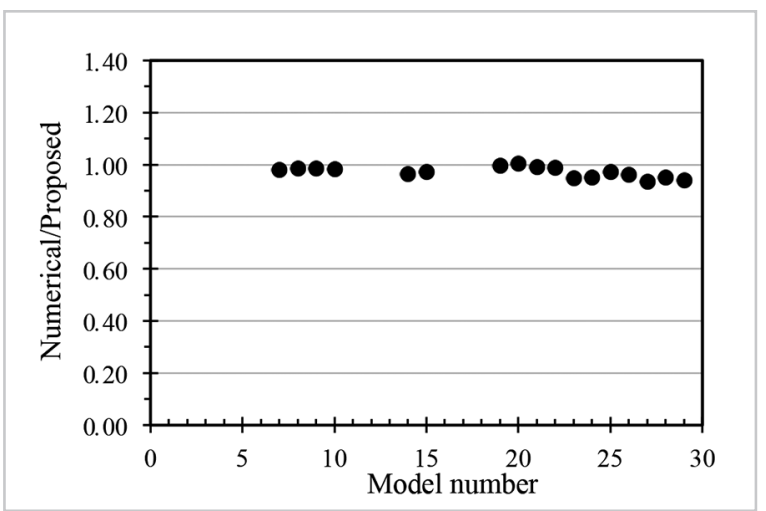

Figure 8 - Comparison between numerical and proposed loads. 
It is observed that the proposed formulation is adequate for calculating bear- ing failure in a 6-bolt configuration and in the geometric and material limits analyzed.

\section{Conclusions}

A numerical model representing a complete sleeve connection was developed, with two outer tubes, one inner tube and aligned bolts. The element types and finite element mesh sizes were evaluated for the numerical representation of the connection.

For the connection with 4 bolts, bearing failure was observed. Shear failure of the bolts was noted right after the occurrence of bearing failure, which indicates that it was close to becoming the dominant mode. Thus, to favor safety and avoid shear failure of bolts, it is recom- mended to use a minimum of 6 bolts for sleeve connections with circular hollow sections under compression.

In all numerical models analyzed, bearing failure was the dominant failure mode. In models in which the outer and inner tubes had the same thickness value, the failure was observed in the inner tube, except for the cases with 4 bolts. Therefore, these cases were not considered in further analysis, and connections with these geometric properties should be avoided in the design of sleeve connections.
Considering the models with 6 bolts and failure in the outer tube, a dispersion was observed in the values between the numerical and theoretical - ABNT NBR 8800 (2008) - loads, with a medium ratio of 0.614 .

Finally, a new formulation for the determination of the resistance of sleeve connections between circular hollow sections and under bearing failure was proposed. The ratio between the numerical and proposed loads was close to 1.0, with a medium ratio of 0.971 .

\section{Acknowledgements}

The authors are grateful for the support from FAPEMIG, CAPES, CNPq, UFSJ and UFOP.

\section{References}

AMPARO, L. R. Análise teórico-experimental de ligações tipo luva compostas por perfis tubulares com parafusos em linha e cruzados. 2014. 80 f. Dissertação (Mestrado em Engenhaia Civil) - Escola de Minas, Universidade Federal de Ouro Preto, 2014.

AMPARO, L. R.; ESCANIO, L. A.; SARMANHO, A. M.; PEREIRA, C. O. V. R. Análise numérica e experimental de ligação tipo luva em perfis tubulares com parafusos cruzados. In: IBERIAN LATIN-AMERICAN CONGRESS ON COMPUTATIONAL METHODS IN ENGINEERING, 36., 2015, Rio de Janeiro. Proceedings [...]. Rio de Janeiro: CILAMCE, 2015a.

AMPARO, L. R.; SARMANHO, A. M.; ARAÚJO, A. H. M.; REQUENA, J. A. V. Analysis of the possible failure modes in CSH bolted sleeve connections. In: INTERNATIONAL SYMPOSIUM ON TUBULAR STRUCTURES, 15., 2015, Rio de Janeiro. Proceedings [...]. Rio de Janeiro: CRC Press / Balkem, 2015b.

AMPARO, L. R.; ESCANIO, L. A.; SARMANHO, A. M.; REQUENA, J. A. V. Avaliação da influência da variação do número de parafusos na ligação tipo luva em perfis tubulares com parafusos cruzados. In: IBERIAN LATIN-AMERICAN CONGRESS ON COMPUTATIONAL METHODS IN ENGINEERING, 37., 2016, Brasília. Proceedings [...]. Brasília: CILAMCE, 2016.

ANSYS INC. ANSYS. Versão 12.0. Pensilvânia, EUA: ANSYS Inc., 2012.

ARAÚJO, A. H. M.; SARMANHO, A. M. C.; BATISTA, E. M.; REQUENA, J. A. V.; FAKURY, R. H.; PIMENTA, R. J. Projeto de estruturas de edificações com perfis tubulares de aço. 1. ed. Belo Horizonte: Editora Vallourec, 2016.

ASSOCIAÇÃO BRASILEIRA DE NORMAS TÉCNICAS. ABNT NBR 8800: Projeto de estruturas de aço e de estruturas mistas de aço e concreto de edifícios. Rio de Janeiro: ABNT, 2008.

LIU, Q.; YANG, J.; WANG, F. Numerical simulation of sleeve connections for cold formed steel sigma sections. Engineering Structures, v. 100, p. 686-695, 1 Oct. 2015.

LUO, F. J.; BAI, Y.; YANG, X.; LU, Y. Bolted sleeve joints for connecting Pultruded FRP tubular components. Journal of Composites for Construction, v. 20, n. 1, p. 04015024, Feb. 2016.

NATESAN, V.; MADHAVAN, M. Structural performance on bolted sleeved connections between two CFS channel sections subjected to combined bending and shear. Structures, v. 20, p. 794-812, 1 Aug. 2019.

ROQUETE, L. Estudo de ligações tipo luva em perfis tubulares. 2018. Tese (Doutorado em Engenharia Civil) - Escola de Minas, Universidade Federal de Ouro Preto, 2018.

ROQUETE, L.; SARMANHO, A. M. C.; ESCANIO, L. A.; SOUZA, D. L. C.; OLIVEIRA, M. M. Identificação de modos de falha em perfis tubulares com ligação tipo luva e parafusos cruzados a $90^{\circ}$ usando um modelo numérico. In: IBERIAN LATIN-AMERICAN CONGRESS ON COMPUTATIONAL METHODS IN ENGINEERING, 38., 2017, Florianópolis. Proceedings [...]. Florianóplis: CILAMCE, 2017a.

ROQUETE, L.; SARMANHO, A. M. C.; MAZON, A. A. O.; REQUENA, J. A. V. Influence of shear lag coefficienton circular hollow sections with bolted sleeve connections. REM - International Engineering Journal, v. 70, n. 4, p. 393-398, dec. 2017b.

SALMON, C. G.; JOHNSON, J. E. Steel structures: design and behavior emphasizing load and resistance factor design. 3. ed. New York: Harper Collins College Publishers, 1990. 
SILVA, J. M. Análise Téorico-experimental de ligações tubulares tipo luva. 2012. Dissertação (Mestrado em Engenharia Civil) - Escola de Minas, Universidade Federal de Ouro Preto, 2012.

VIEIRA, R. C. Análise numérica e experimental de ligações tubulares de aço do tipo luva parafusada. 2014. Tese (Doutorado em Engenharia Civil) - Faculdade de Engenharia Civil, Arquitetura e Urbanismo, Universidade Estadual de Campinas, 2014.

VIEIRA, R. C.; VIEIRA, R. F.; REQUENA, J. A. V.; ARAÚJO, A. H. M. Numerical analysis of CHS bolted sleeve connections. In: EUROSTEEL 2011, 6 th, 2011, Budapest, Hungary. Proceedings [...]. Budapest, Hungary: ECCS Press, 2011.

WARDENIER, J.; PACKER, J. A.; ZHAO, X.-L.; VEGTE, A. VAN DE. Hollow sections in structural applications. 2nd. ed. Genebra: CIDECT, 2010.

ZHANG, Z.; WU, C.; NIE X.; BAI, Y.; ZHU, L. Bonded sleeve connections for joining tubular GFRP beam to steel member: Numerical investigation with experimental validation. Composite Structures, v. 157, p. 51-61, 1 Dec. 2016.

Received: 19 September 2019 - Accepted: 18 November 2019. 